\title{
Deskripsi Kesulitan Belajar Matematika Siswa pada Materi Bangun Datar Ditinjau dari Segi Kemampuan Koneksi Matematika Siswa
}

\author{
Asdar $^{1,}$ a) Fajar $^{1, \text { b) }}$, dan Rahmawati ${ }^{1, c)}$ \\ ${ }^{1}$ Jurusan Matematika, Fakultas MIPA, Universitas Negeri Makassar \\ a)asdar@unm.ac.id

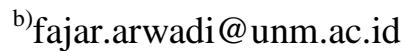 \\ c)rahmawati.mmicp15@gmail.com
}

\begin{abstract}
Abstrak. Penelitian ini bertujuan untuk mengetahui deskripsi kesulitan siswa dalam belajar matematika pada pokok bahasan bangun datar, ditinjau dari segi kemampuan koneksi matematika siswa. Penelitian ini adalah penelitian kualitatif menggunakan pendekatan deskriptif. Pengambilan subjek dilakukan dengan memberikan lembar tes kemampuan koneksi matematika kepada siswa kelas VIII yang kemudian dari hasil tersebut dipilih secara purposive 5 subjek. Instrumen yang digunakan adalah instrumen tes kemampuan koneksi, tes diagnostik kesulitan belajar dan pedoman wawancara. Indikator kesulitan belajar yaitu abnormalitas persepsi visual, gangguan hubungan keruangan, asosiasi visual-motor, kesulitan memahami simbol, kesulitan bahasa dan membaca. Hasil penelitian menunjukkan : 1) subjek dengan kemampuan koneksi matematika baik sekali mengalami gangguan hubungan keruangan, 2) subjek dengan kemampuan koneksi matematika baik mengalami gangguan hubungan keruangan dan asosiasi visual motor, 3) subjek dengan kemampuan koneksi matematika cukup mengalami abnormalitas persepsi visual, gangguan hubungan keruangan dan asosiasi visual motor, 4) subjek dengan kemampuan koneksi matematika kurang mengalami gangguan hubungan keruangan, asosiasi visual motor, abnormalitas persepsi visual, kesulitan bahasa dan membaca, 5) subjek dengan kemampuan koneksi matematika sangat kurang mengalami kesulitan disemua indikator kesulitan belajar.
\end{abstract}

Kata Kunci: Kesulitan Belajar, Kemampuan Koneksi Matematika, Bangun Datar

\begin{abstract}
This research aims to know the description of students' learning difficulties in learning mathematics on the topik of Plane viewed from students' mathematical connection ability. This research is descriptive research using a qualitative approach. Retrieval of the subject is formed by providing mathematical connection ability tests to students of class VIII and from the result of mathematical connection ability selected purposively 5 subjects. The instrument in this research is the test of mathematics connection ability, a diagnostik test of mathematics learning difficulties, and interview guidelines. Students' learning difficulties analyzed base on 5 indicators of learning difficulties, it contains abnormality of visual perception, interference of spatial relation, the association of visual-motor, difficulty in understanding symbol, difficulty in language and reading. The results showed that (1) subject with very good mathematical connection ability feel difficult in interference of spatial relation, (2) subject with good mathematical connection ability find difficulties in interference of spatial relation and association of visual-motor, (3) subject with moderate mathematical connection ability find difficulties in abnormality of visual perception, interference of spatial relation and association of visual-motor, (4) subject with low mathematical connection ability find difficulties in interference of spatial relation, association of visual-motor, abnormality in visual perception, difficulty in language and reading, (5) subject with very low mathematical connection ability experience difficulties in all the indicators of learning difficulties.
\end{abstract}

Keywords: Learning Difficulty, Connection Ability, Mathematics, Plane 


\section{PENDAHULUAN}

Kesulitan belajar merupakan suatu kondisi tertentu yang ditandai dengan adanya hambatanhambatan dalam kegiatan mencapai tujuan pembelajaran, sehingga memerlukan usaha lebih giat lagi untuk dapat mengatasinya (Mulyadi,2010). Kumalasari \& Putri (2013) mengatakan bahwa kesulitan belajar matematika pada siswa berhubungan dengan kemampuan belajar yang kurang sempurna. Kekurangan tersebut dapat terungkap dari penyelesaian persoalan matematika yang tidak tuntas atau tuntas tetapi salah. Ketidaktuntasan tersebut diduga karena kesalahan penggunaan konsep dan prinsip dalam menyelesaikan persolan matematika yang diperlukan.

Beberapa penelitian telah mengkaji tentang kesulitan belajar. Nurrahmah (2018) telah melakukan penelitian tentang deskripsi kesulitan siswa dalam menyelesaikan soal matematika materi dimensi tiga pada kelas VIII. Hasilnya menunjukkan bahwa kesulitan belajar matematika yang dialami oleh siswa terbagi atas 4 tipe yaitu kesulitan fakta, kesulitan konsep, kesulitan operasi, dan kesulitan prinsip. Anfus (2017) meneliti tentang deskripsi kesulitan belajar matematika siswa ditinjau dari gaya kognitif dengan model pembelajaran Think Pair Share (TPS) pada siswa kelas VIII. Hasilnya menunjukkan bahwa Siswa yang memiliki gaya kognitif Field Dependent cenderung mengalami kesulitan gangguan hubungan keruangan, serta kesulitan mengenal dan memahami simbol, sedangkan siswa yang memiliki gaya kognitif Field Independent cenderung mengalami kesulitan perseverasi, serta kesulitan dalam bahasa dan membaca.

Dalam penelitian ini, dikaji kesulitan siswa dalam menyelesaikan soal bangun datar ditinjau dari segi kemampuan koneksi matematika siswa. Jenis kesulitan yang dikaji dalam penelitian ini adalah jenis kesulitan belajar menurut Lerner, yaitu: (1) gangguan hubungan keruangan, (2) abnormalitas persepsi visual, (3) asosiasi visual-motor, (4) kesulitan mengenal dan memahami simbol, dan (5) kesulitan dalam bahasa dan membaca. Adapun tujuan dari penelitian ini adalah untuk mendeskripsikan kesulitan belajar yang dialami oleh siswa ditinjau dari kemampuan koneksi matematika siswa.

Mata pelajaran matematika terdiri dari berbagai topik yang saling berkaitan satu sama lain. Keterkaitan tersebut tidak hanya antar topik dalam matematika, tetapi terdapat juga keterkaitan dengan disiplin ilmu lain dan dengan kehidupan sehari-hari (Kumalasari \& Putri, 2013). Menurut Ruspiani (2000) kemampuan mengkaitkan konsep-konsep matematika baik antar konsep matematika itu sendiri maupun mengkaitkan konsep matematika dengan bidang lainnya disebut kemampuan koneksi matematika. Tanpa kemampuan koneksi matematika, siswa akan mengalami kesulitan mempelajari matematika karena jika siswa tidak mengaitkan antara topik yang satu dengan topik yang lainnya maka siswa akan dibebankan oleh banyaknya rumus yang diberikan (Setiawan, 2009). Menurut NCTM (2000) tanpa koneksi matematika maka siswa harus belajar dan mengingat terlalu banyak konsep dan prosedur matematika yang saling terpisah.

Beberapa penelitian telah mengkaji tentang kemampuan koneksi matematika. Anandita (2015) telah melakukan penelitian tentang analisis kemampuan koneksi matematis siswa SMP kelas VIII pada materi kubus dan balok. Hasilnya menunjukkan bahwa kemampuan koneksi matematis siswa terbagi atas 6 tipe, yaitu: (1) Memahami hubungan dari berbagai representasi tentang konsep dan prosedur matematika. (2) Memahami hubungan antar topik dalam matematika. (3) Mampu menggunakan matematika dalam penyelesaian masalah dalam kehidupan sehari-hari. (4) Memahami representasi konsep yang ekuivalen. (5) Menemukan hubungan antara prosedur satu dengan yang lainnya yang ekuivalen. (6) Menggunakan koneksi antara matematika dengan matematika sendiri maupun dengan ilmu yang lainnya. Isnaeni, Ansori,Akbar,\&Bernard (2019) telah melakukan penelitian tentang analisis kemampuan koneksi 
matematis siswa SMP pada materi persamaan dan pertidaksamaan linear satu variabel. Hasilnya menunjukkan bahwa kemampuan koneksi matematis siswa SMP kelas VII tergolong tinggi.

\section{KAJIAN PUSTAKA}

\section{Kesulitan Belajar Matematika}

Aktifitas berpikir setiap individu tidak selamanya berlangsung secara wajar, karena dalam proses pembelajaran, siswa terkadang sulit untuk berkonsentrasi sehingga membuat siswa mengalami kesulitan dalam belajar. Menurut Ahmadi \& Supriyono (2013) Kesulitan belajar adalah keadaan dimana siswa tidak dapat belajar sebagaimana mestinya. Sementara itu, Mulyadi (2010) menyatakan bahwa kesulitan belajar merupakan suatu kondisi dalam proses belajar yang ditandai dengan adanya hambatan-hambatan tertentu untuk mencapai hasil belajar.

Kesulitan belajar matematika terdiri atas berbagi jenis. Menurut Putri (2008) jenis kesulitan yang sering dialami siswa dalam menyelesaikan persoalan dalam matematika yaitu: 1) Tidak paham konsep-konsep sederhana; 2) Tidak mengetahui maksud soal; 3) Tidak bisa menerjemahkan soal kedalam kalimat matematika; 4) Tidak bisa menyelesaikan kalimat matematika; 5) Tidak cermat dalam menghitung; 6) Kesalahan dalam menulis angka.. Selain itu, Menurut Lerner (2006) ada beberapa jenis kesulitan belajar matematika yang dialami oleh anakanak, yaitu; (1) adanya gangguan dalam hubungan keruangan, (2) abnormalitas persepsi visual, (3) asosiasi visual-motor, (4) perseverasi, (5) kesulitan memahami simbol, (6) gangguan penghayatan tubuh, (7) kesulitan dalam bahasa dan membaca, (8) skor Performance $I Q$ jauh lebih rendah daripada skor Verbal IQ.

Dalam penelitian ini, indikator yang digunakan untuk mendiagnosis kesulitan belajar matematika siswa berdasarkan pendapat lerner, yaitu:

- Gangguan Hubungan Keruangan, yaitu adanya gangguan dalam memahami konsepkonsep hubungan yang dapat mengganggu pemahaman anak tentang sistem bilangan secara keseluruhan. Karena adanya gangguan tersebut, anak mungkin tidak mampu merasakan jarak antara angka-angka pada garis bilangan atau penggaris dan mungkin anak juga tidak tahu bahwa angka 3 lebih dekat ke angka 4 daripada ke angka 6.

- Abnormalitas Persepsi Visual, yaitu kesulitan yang dialami seorang anak untuk melihat berbagai objek dalam hubungannya dengan kelompok atau set. Anak yang memiliki abnormalitas visual juga sering tidak mampu membedakan bentuk-bentuk geometri.

- Asosiasi Visual-Motor, yaitu kondisi yang dialami anak berupa kesulitan dalam menghitung benda-benda secara berurutan sambil menyebutkan bilangannya "Satu, dua, tiga, empat, lima." Anak mungkin baru memegang benda yang ketiga tetapi telah mengucapkan "lima", atau sebaliknya , telah menyentuh benda kelima tetapi baru mengucapkan "tiga." Anak-anak semacam ini dapat memberikan kesan mereka hanya menghafal bilangan tanpa memahami maknanya.

- Kesulitan Mengenal dan Memahami Simbol, yaitu kesulitan dalam mengenal dan menggunakan simbol-simbol matematika seperti,,$+-=,>,<$, dan sebagainya.

- Kesulitan dalam Bahasa dan Membaca, Kesulitan dalam bahasa dapat berpengaruh terhadap kemampuan anak dibidang matematika. Soal matematika yang berbentuk cerita menuntut kemampuan membaca untuk memecahkannya. Oleh karena itu, anak yang mengalami kesulitan membaca akan mengalami kesulitan pula dalam memecahkan soal matematika yang berbentuk cerita tertulis.

Beberapa penelitian telah mengkaji tentang kesulitan belajar. Anfus (2017) meneliti tentang deskripsi kesulitan belajar matematika siswa ditinjau dari gaya kognitif dengan model pembelajaran Think Pair Share (TPS) pada siswa kelas VIII. Hasil penelitian yang diperoleh adalah kesulitan belajar matematika siswa menurut lerner ditinjau dari gaya kognitif siswa, 
dikelompokkan menjadi 2 yaitu: (1) Siswa yang memiliki gaya kognitif Field Dependent cenderung mengalami kesulitan: a) gangguan hubungan keruangan yaitu siswa mengalami kesulitan dalam menulis satuan luas dan voume bangun ruang dan mengalami kesulitan dalam membedakan atau menentukan rumus bangun ruang; b) kesulitan mengenal dan memahami simbol yaitu siswa mengalami kesulitan dalam menggunakan simbol-simbol matematika. (2) Siswa yang memiliki gaya kognitif Field Independent cenderung mengalami kesulitan: a) perseverasi yaitu siswa mengalami kesulitan dalam mengoperasikan soal dengan adanya gangguan yang melekat pada objek tertentu; b) kesulitan dalam bahasa dan membaca yaitu siswa mengalami kesulitan dalam memecahkan soal matematika berbentuk cerita.

Hal senada juga dilakukan oleh Nurrahmah (2018). Ia meneliti tentang deskripsi kesulitan siswa dalam menyelesaikan soal matematika materi dimensi tiga pada kelas VIII. Hasil penelitian tersebut menunjukkan bahwa kesulitan belajar matematika yang dialami oleh siswa terbagi atas 4 tipe yaitu kesulitan fakta, kesulitan konsep, kesulitan operasi, dan kesulitan prinsip.

\section{Kemampuan Koneksi Matematika}

Kemampuan koneksi matematika diperlukan oleh siswa dalam mempelajari beberapa topik matematika yang memang saling terkait satu sama lain. Menurut Kumalasari \& Putri (2013) Kaitan antar topik dalam matematika, matematika dengan ilmu lain dan matematika dengan kehidupan sehari hari disebut koneksi matematika. Sementara itu, menurut Isnaeni dkk (2019) kemampuan koneksi matematika adalah kemampuan siswa dalam mencari hubungan suatu representasi konsep dan prosedur, memahami antar topik matematika, dan kemampuan siswa mengaplikasikan konsep matematika dalam bidang lain atau dalam kehidupan sehari-hari.

Kemampuan koneksi matematika terdiri atas berbagai aspek. Sugiman (2008) menyebutkan bahwa kemampuan koneksi memiliki 4 aspek yaitu (1) koneksi inter topik matematika yang mengkaitkan antar konsep atau prinsip dalam satu topik yang sama, (2) koneksi antar topik dalam matematika yang mengaitkan antara materi dalam topik tertentu dengan materi dalam topik lainnya, (3) koneksi antara materi dengan ilmu lain selain matematika, dan (4) koneksi dengan kehidupan sehari-hari yang mungkin dijumpai anak. Sementara itu, menurut NCTM (2000) koneksi matematika terdiri atas tiga aspek, yaitu :

- Aspek Koneksi antar topik matematika. Aspek ini membantu siswa dalam menghubungkan konsep-konsep matematika untuk menyelesaikan suatu situasi permasalahan matematika. Contohnya:Menghitung sisa suku banyak, maka langkah penyelesaiannya dengan melalui proses aljabar (subtitusi) dan proses bagan (pembagian bersusun, horner), Menentukan luas suatu bangun datar dengan menggunakan operasi aljabar, Pecahan dihubungkan dengan desimal dan persen, Bilangan bulat dengan garis bilangan, Segitiga dihubungkan dengan trigonometri

- Aspek koneksi dengan dengan disiplin ilmu lain. Aspek ini menunjukkan bahwa matematika sebagai disiplin ilmu dapat bermanfaat bagi perkembangan disiplin ilmu lain - Contohnya: Ekonomi (menghitung analisis keuangan, keuntungan produk, saldo dan sebagainya), Fisika (menghitung kecepatan kendaraan), Kimia (menentukan PH suatu larutan, menghitung persentase kebutuhan alkohol), Geografi (menghitung ph tanah dan kelembapan tanah).

- Aspek koneksi dengan dunia nyata. Aspek ini menunjukkan bahwa matematika dapat bermanfaat untuk menyelesaikan masalah dalam kehidupan sehari-hari. Contohnya :untuk menyelesaikan masalah mengenai aritmetika sosial.

Beberapa penelitian telah mengkaji tentang kemampuan koneksi matematika. Anandita (2015) telah melakukan penelitian tentang analisis kemampuan koneksi matematis siswa SMP kelas VIII pada materi kubus dan balok. Hasilnya menunjukkan bahwa kemampuan koneksi matematis siswa terbagi atas 6 tipe, yaitu: (1) Memahami hubungan dari berbagai representasi tentang konsep dan prosedur matematika. (2) Memahami hubungan antar topik dalam 
matematika. (3) Mampu menggunakan matematika dalam penyelesaian masalah dalam kehidupan sehari-hari. (4) Memahami representasi konsep yang ekuivalen. (5) Menemukan hubungan antara prosedur satu dengan yang lainnya yang ekuivalen. (6) Menggunakan koneksi antara matematika dengan matematika sendiri maupun dengan ilmu yang lainnya.

Hal senada juga dilakukan oleh Isnaeni dkk (2019). Ia telah melakukan penelitian tentang analisis kemampuan koneksi matematis siswa SMP pada materi persamaan dan pertidaksamaan linear satu variabel. Subjek penelitiannya adalah siswa kelas VII sebanyak 39 orang. Hasil penelitian tersebut menunjukkan bahwa kemampuan koneksi matematis siswa SMP kelas VII tergolong tinggi.

\section{METODE PENELITIAN}

Penelitian ini merupakan jenis penelitian deskriptif dengan menggunakan pendekatan kualitatif. Subjek penelitian ini adalah tiga orang siswa kelas VIII. Setiap subjek ini mewakili satu ketegori kemampuan koneksi matematika, yaitu kemampuan koneksi matematika baik (SK1), cukup (SK2), dan Kurang (SK3).

Teknik pengumpulan data dalam penelitian ini adalah tes dan wawancara. Adapun instrumen yang digunakan adalah tes kemampuan koneksi matematika, tes diagnostik kesulitan belajar dan pedoman wawancara. Tes kemampuan koneksi matematika digunakan untuk mengelompokkan calon subjek penelitian kedalam lima kategori kemampuan koneksi matematika. Tes diagnostik kesulitan belajar digunakan untuk mengungkap jenis kesulitan belajar yang dialami oleh siswa. Pedoman wawancara digunakan untuk memudahkan peneliti dalam menggali informasi mengenai kesulitan belajar yang dialami oleh siswa.

Tes kemampuan koneksi matematika diberikan kepada siswa kelas VIII SMP yang merupakan calon subjek penelitian. Berdasarkan hasil tes, calon subjek dikelompokkan kedalam kategori kemampuan koneksi matematika baik, cukup, dan kurang. Satu subjek dipilih pada setiap kategori untuk diberikan tes kesulitan belajar. Kemudian dilakukan analisa terhadap jawaban subjek berdasarkan 5 indikator kesulitan belajar matematika. Informasi yang dianggap kurang mendalam dijadikan catatan untuk bahan wawancara. Selain untuk menggali informasi secara lebih mendalam, wawancara juga dilakukan untuk mengkonformasi jawaban subjek pada tes kesulitan belajar matematika.

\section{HASIL DAN PEMBAHASAN}

Pada bagian ini dipaparkan data hasil penelitian, berupa jawaban subjek pada tes kesulitan belajar matematika dan transkrip wawancara. Pembahasan hasil penelitian dibagi berdasarkan subjek penelitian, yaitu subjek dengan kemampuan koneksi matematika baik, cukup, dan kurang. Kesulitan belajar matematika subjek pada setiap aspek dideskripsikan melalui jawaban subjek dan/atau transkrip wawancara. Berikut ini adalah soal tes diagnostik kesulitan belajar matematika yang diberikan kepada ketiga subjek penelitian.

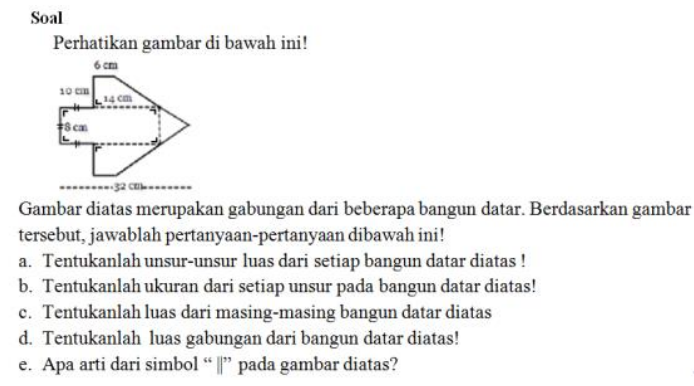

GAMBAR 1. Soal Tes Diagnostik Kesulitan Belajar Matematika 


\section{Deskripsi Kesulitan Belajar Subjek dengan Kemampuan Koneksi Matematika Baik (SK 1)}

Berikut ini disajikan jawaban subjek pada soal diagnostik kesulitan belajar.

$$
\left.\begin{array}{l}
\text { b. Segitiga }=8 \mathrm{~cm} \text { dan } 10 \mathrm{~cm} \\
\text { persegi }=8 \mathrm{~cm} \\
\text { Persegipanjang }=8 \mathrm{~cm} \text { dan } 22 \mathrm{~cm} \\
\text { Trapesium }=6 \mathrm{~cm} \text { dar } 14 \mathrm{~cm}
\end{array}\right\} \begin{aligned}
& \mathrm{S} 1-\mathrm{T} 1 \mathrm{~b} 1 \\
& \mathrm{~S} 1-\mathrm{T} 1 \mathrm{~b} 2
\end{aligned}
$$

GAMBAR 2. Jawaban SK 1

Pada Gambar 1 terlihat bahwa subjek menuliskan alas dan tinggi segitiga masing-masing $8 \mathrm{~cm}$ dan $10 \mathrm{~cm}$, sisi persegi adalah $8 \mathrm{~cm}$, panjang dan lebar persegi panjang masing-masing $8 \mathrm{~cm}$ dan $22 \mathrm{~cm}$, serta dua sisi sejajar pada trapesium masing-masing $6 \mathrm{~cm}$ dan $14 \mathrm{~cm}$. hasil tersebut menunjukkan bahwa subjek menganggap bangun persegi berada di dalam bangun persegi panjang, sehingga seharusnya ukuran panjang pada bangun persegipanjang adalah $14 \mathrm{~cm}$ malah dituliskan $22 \mathrm{~cm}$ (S1-T1b1). Selain itu, subjek tidak menuliskan secara lengkap ukuran untuk unsur bangun pada trapesium, melainkan hanya menuliskan ukuran untuk dua sisi sejajar pada trapesium, tidak menambahkan ukuran untuk unsur tinggi pada trapesium (S1-T1b2). Jadi subjek tidak mampu menentukan ukuran panjang pada bangun persegi panjang dengan tepat dan tidak mampu menentukan ukuran untuk unsur tinggi pada bangun trapesium.

Dengan demikian, subjek tidak dapat menentukan semua sisi-sisi yang bersesuaian beserta ukurannya pada bangun datar yang diberikan. Hal ini diperjelas dalam kutipan wawancara pada Transkrip 1.

\section{TRANSKRIP 1}

P1-W1b1 Bagaimana ditentukan panjang dan lebar persegi panjang nya?

S1-WIb1 Ini di gambar kak yang berbentuk persegi panjang batasnya sampai disini, karena panjang nya itu disini tertulis 14 dan disini 8 maka total panjangnya 14+8 $=22$ dan lebarnya itu ini kak $8 \mathrm{~cm}$ ( siswa menjelaskan sambil menunjuk gambar pada soal)

P1-W1b2 Kalau sisi pada persegi nya?

S1-W1b2 Ini kak, kan gambar perseginya itu ini yang ada tanda sisi yang sama panjang, yang $8 \mathrm{~cm}$ semua. ( siswa menjelaskan sambil menunjuk lembar soal)

P1-W1b3 Tidak double ji itu kah dek, karena kita gabungkan ukuran panjang persegi panjang dengan ukuran sisi pada persegi?

S1-WIb3 Menurutku tidak ji itu kak, begitu mi kayaknya.

Pada Transkrip 1, terlihat bahwa subjek menentukan ukuran pada persegi dan persegi panjang dengan memperhatikan bentuk bangun yang sesuai beserta batas-batasnya (S1-W1b1), namun subjek keliru dengan menggabungkan nilai unsur panjang pada persegi panjang dan nilai unsur sisi pada persegi (S1-W1b2, S1WIb3 ).

Dengan demikian, subjek kesulitan dalam menentukan sisi-sisi yang bersesuaian untuk bangun datar yang berhimpit dan memiliki bentuk yang hampir sama. Hal ini menunjukkan bahwa SK 1 mengalami gangguan hubungan keruangan. 


\section{Deskripsi Kesulitan Subjek dengan Kemampuan Koneksi Matematika Cukup ( SK} 2)

Berikut ini disajikan jawaban subjek pada soal diagnostik kesulitan belajar

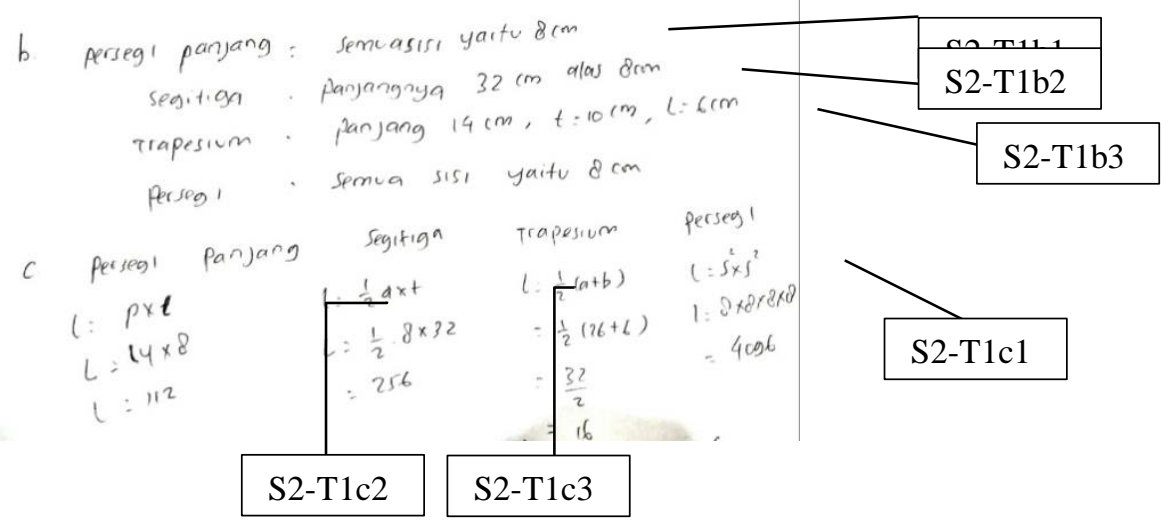

GAMBAR 3. Jawaban SK 2

Pada Gambar 3 terlihat bahwa subjek menuliskan ukuran semua sisi persegi panjang yaitu 8 $\mathrm{cm}$, panjang dan alas segitiga masing-masing $32 \mathrm{~cm}$ dan $8 \mathrm{~cm}$, kemudian panjang, tinggi dan lebar trapesium masing-masing $14 \mathrm{~cm}, 10 \mathrm{~cm}$, dan $6 \mathrm{~cm}$, serta semua sisi pada persegi yaitu 8 $\mathrm{cm}$. Hasil tersebut menunjukkan bahwa subjek tidak mampu menentukan unsur-unsur luas beserta ukurannya pada bangun datar yang diberikan, sehingga yang seharusnya unsur luas pada persegi panjang yaitu panjang dan lebar, malah dituliskan sisi (S2-T1b1), untuk segitiga yang seharusnya alas dan tinggi malah dituliskan panjang dan alas (S2-T1b2), untuk trapesium yang seharusnya dua sisi sejajar dan tinggi malah dituliskan panjang, tinggi dan lebar (S2-T1b3). Selain kekeliruan dalam menentukan unsur luas pada setiap bangun datar, subjek juga keliru dalam menentukan ukuran pada setiap unsurnya.

Kemudian subjek menuliskan rumus luas pada persegi panjang yaitu $p \times l$ dan memperoleh hasil $112 \mathrm{~cm}^{2}$, untuk segituga yaitu $\frac{1}{2} a \times t$ dan memperoleh hasil $256 \mathrm{~cm}^{2}$, untuk trapesium yaitu $\frac{1}{2}(a+b)$ dan memperoleh hasil $16 \mathrm{~cm}^{2}$, serta untuk persegi yaitu $s^{2} \times s^{2}$ dan memperoleh hasil $4096 \mathrm{~cm}^{2}$. Hal ini menunjukkan bahwa subjek tidak mampu menentukan rumus yang tepat untuk bangun trapesium, yang seharusnya menggunakan rumus $\frac{1}{2}(a+b) \times t$ malah dituliskan $\frac{1}{2}(a+b)$ (S2-T1c3), dan untuk bangun persegi yang seharusnya $s \times s$ malah dituliskan $s^{2} \times s^{2}(\mathrm{~S} 2-\mathrm{T} 1 \mathrm{c} 1)$. Dengan kekeliruan dalam menentukan rumus, maka keliru pula lah dalam memperoleh jawaban yang diminta. Penentuan luas untuk bangun persegi panjang sudah tepat karena rumus yang digunakan sudah tepat dan ukuran unsur luas yang diminta sudah tepat, namun untuk bangun segitiga, walaupun rumus yang digunakan sudah tepat tetapi ukuran unsur tinggi yang digunkana tidak tepat, yang seharusnya $10 \mathrm{~cm}$ malah dituliskan $32 \mathrm{~cm}$ (S2-T1c2).

Dengan demikian, subjek tidak dapat menentukan unsur luas beserta ukuran masing-masing unsur luas pada gambar yang diberikan dan tidak mampu menentuka rumus yang tepat untuk mencari luas masing-masing bangun datar tersebut. Hal ini diperjelas dalam kutipan wawancara pada transkrip 2 . 


\section{TRANSKRIP 2}

P2-W1b1 Bagaimana ditentukan unsur luas persegi panjang nya?

S2-W1b1 Kuliat dulu ini kak yang bentuknya persegi panjang, dan ini ada tanda sama semua ukuran sisinya yaitu $8 \mathrm{~cm}$, jadi itumi kak, semua sisinya itu $8 \mathrm{~cm}$ ( siswa menjelaskan sambil menunjuk gambar pada soal)

P2-W1b2 Bagaimana cara dicari unsur luas segitiganya?

S2-W1b2

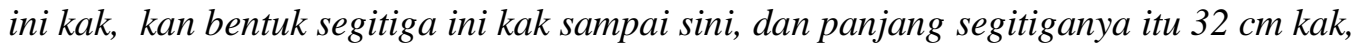
dan alas segitiganya itu ini kak, $8 \mathrm{~cm}$. (siswa menjelaskan sambil menunjuk gambar soal)

Pada Transkrip 3, terlihat bahwa subjek menentukan unsur luas pada bangun dengan melihat bentuk pada gambar yang diberikan. Untuk menentukan unsur luas pada persegi panjang, subjek melihat simbol $=$ pada gambar dan menganggap bahwa ukuran semua unsur luas pada persegi panjang adalah $8 \mathrm{~cm}$ (S2-W1b1), kemudian sujek menentukan alas dan tinggi segitiga yaitu masing-masing $32 \mathrm{~cm}$ dan $8 \mathrm{~cm}$. hasil tersebut menunjukkan bahwa subjek menganggap gabungan 1 segitiga dan 2 trapesium adalah sebuah segitiga, sehingga menuliskan tinggi segitiga yaitu $32 \mathrm{~cm}$, padahal seharusnya $10 \mathrm{~cm}$ (S2-W1b2).

Dengan demikian, subjek kesulitan dalam menentukan unsur luas yang tepat pada lebih dari satu bangun datar, dengan memasukkan unsur luas pada persegi kedalam persegi panjang, kemudian memasukkan unsur luas pada persegi panjang kedalam segitiga dan trapesium. Subjek juga kesulitan dalam menentukan rumus masing-masing bangun datar. Hal ini menunjukkan bahwa, subjek cenderung hanya menghapal topik yang diberikan tanpa pemahaman yang tepat, sehingga subjek kesulitan ketika diberika persoalan bangun datar yang lebih kompleks. Oleh karena itu, dapat diindikasikan bahwa subjek mengalami abnormalitas persepsi visual, gangguan hubungan keruangan dan asosiasi visual motor. Hal ini sesuai dengan yang disampaikan oleh Lerner (2006) anak yang memiliki abnormalitas persepsi visual juga sering tidak mampu membedakan bentuk-bentuk geometri. Mulyadi (2010) juga menyampaikan bahwa, anak yang berkesulitan belajar matematika mungkin memiliki kesulitan dalam mengasosiasikan simbol audiotorik dan visual. Simbol dalam hal ini termasuk notasi yang pada rumus yang ada dalam belajar matematika.

\section{Deskripsi Kesulitan Subjek Keempat ( Kemampuan Koneksi Matematika Kurang)}

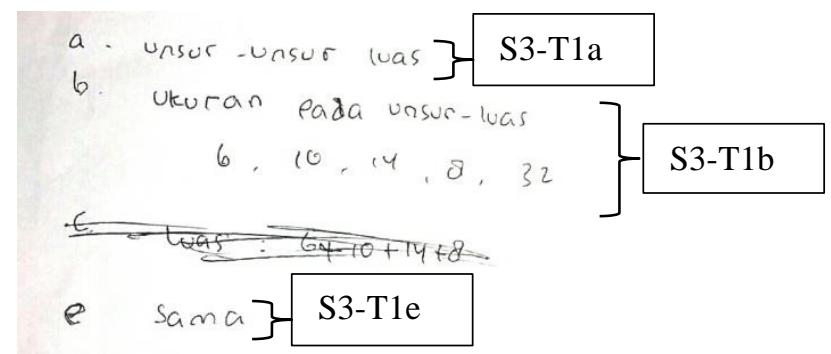

GAMBAR 4. Jawaban SK 3

Pada Gambar 4 terlihat bahwa subjek menuliskan kalimat unsur-unsur luas sebagai jawaban untuk soal bagian a (S3-T1a). Kemudian menuliskan deretan angka untuk ukuran masingmasing unsur luas yaitu 6,10,14,8, dan 32 (S3-T1b). Selanjutnya menuliskan kata sama untuk jawaban ada soal bagian e (S3-T1e).

Dengan demikian, subjek tidak mengetahui unsur-unsur luas beserta ukurannya pada setiap bangun datar, tidak mampu menentukan rumus yang digunakan untuk mencari luas masingmasing bangun datar, tidak memahami simbol yang diberikan pada gambar , bahkan tidak mengetahui maksud soal dengan baik. Hal ini diperjelas dalam kutipan wawancara pada Transkrip 3. 


\section{TRANSKRIP 3}

P3-Wlal Ditau ji kah dek bentuk bangun datar apa ini?

\section{S3-Wlal Tidak kutaui kak}

P3-W1b1 Coba perhatikan gambar,apakah kamu mengetahui sisi-sisi yang ada pada soal?

S3-W1b1 (Diam, sambil garuk kepala)

P3-W1b2 Kakak lihat adek menuliskan deretan angka pada bagian b, apa itu dek?

S3-WIb2 Aih tidak ada mi kutau apa-apa kak, jadi langsung saja kutulis itu angka-angka yang

P3-Wlc1 Kenapa tidak dijawab bagian c dek?

S3-WIcl Tidak kutau I kak

P3-WIc2 pertanyaan selanjutnya, apakah kamu tau rumus apa yang digunakan untuk

S3-W1c2 (menggeleng)

P3-Wle1 apa arti simbol garis dua sama simbol $\lrcorner$ pada soal?

S3-Wle1 yang tanda garis dua itu artinya sama kak, klw - hmm... (garuk kepala).

P3-Wle2 Oh iya, apanya yang sama dek?

S3-Wle2 Pokoknya samai kak... tidak tau deh kak, pusingka

P3-W001 apa kamu kesulitan dalam memahami dan membaca soal?

S3-W001 Iya kak... sulit sekali soal ta'

Pada Transkrip 3, terlihat bahwa subjek tidak mengetahui bangun datar apa yang ada pada soal yang diberikan (S3-Wlal), tidak mengetahui sisi-sisi yang bersesuaian pada soal(S3-Wlb1), tidak mengetahui ukuran masing-masing unsur pada bangun datar yang diberikan sehingga hanya menuliskan deretan angka yang ada pada soal (S3-W1b2), tidak menjawab soal bagian c karena tidak mengetahui rumus yang digunakan untuk menentukan luas pada masing-masing bangun datar (S3-W1c1,S3-W1c2), tidak mengetahui arti simbol pada gambar yang diberikan (S3-W1e1, S3-W1e2), serta tidak memahami soal yang diberikan (S3-W001).

Dengan demikian, subjek kesulitan dalam menjawab semua soal yang diberikan karena subjek tidak memahami soal tersebut dan memang tidak memiliki pengetahuan yang cukup mengenai bangun datar. Jadi, dalam menyelesaikan soal tersebut, subjek mengalami abnormalitas persepsi visual, gangguan hubungan keruangan, asosiasi visual motor, kesulitan memahami simbol, serta kesulitan dalam bahasa dan membaca. Hal ini sejalan dengan pendapat Putri (2008) bahwa kesulitan yang sering dialami siswa dalam menyelesaikan persoalan dalam matematika seperti tidak mengetahui maksud soal.

\section{KESIMPULAN}

Tujuan dari penelitian ini adalah untuk mendeskripsikan kesulitan belajar matematika yang dialami oleh siswa kelas VIII pada materi bangun datar. Hasil penelitian ini menunjukkan bahwa:

1. Subjek dengan kemampuan koneksi matematika baik mengalami kesulitan dalam gangguan hubungan keruangan, berkaitan dengan kesulitan dalam menentukan nilai dari setiap unsur luas pada bangun tersebut.

2. Subjek dengan kemampuan koneksi matematika cukup mengalami kesulitan dalam abnormalitas persepsi visual, gangguan dalam hubungan keruangan dan asosiasi visual motor, berkaitan dengan kesulitan menentukan unsur luas pada bangun datar dengan tepat, kesulitan menentukan sisi-sisi yang bersesuaian yang ada pada soal dan ketidakmampuan mengingat rumus dengan baik. 
3. Subjek dengan kemampuan koneksi matematika kurang mengalami kesulitan disemua indikator kesulitan belajar matematika.hal ini berkaitan dengan kesulitan dalam menentukan bangun datar apa yang ada pada soal yang diberikan, kesulitan menentukan sisi-sisi yang bersesuaian pada soal, kesulitan menentukan ukuran masing-masing unsur pada bangun datar yang diberikan sehingga hanya menuliskan deretan angka yang ada pada soal, kesulitan menentukan rumus yang digunakan untuk menentukan luas pada masing-masing bangun datar, kesulitan memahami arti simbol pada gambar yang diberikan, serta kesulitan memahami soal yang diberikan.

\section{DAFTAR PUSTAKA}

Ahmadi, \& Supriyono. (2013). Psikologi Belajar. Jakarta: Rineka Cipta.

Anandita, G.P. (2015). Analisis Kemampuan Koneksi Matematis Siswa SMP Kelas VIII Pada Materi Kubus dan Balok. (Skripsi). Universitas Negeri Semarang, Semarang.

Anfus, A.S.N.(2017). Deskripsi Kesulitan Belajar Matematika Siswa Ditinjau dari Gaya Kognitif dengan Model Pembelajaran Think Pair Share (TPS) Pada Siswa Kelas VIII. (Skripsi). Universitas Muhammadiyah Surakarta, Surakarta.

Isnaeni, S., Ansori, A., Akbar, P., \& Bernard, M. (2019). Analisis Kemampuan Koneksi Matematis Siswa SMP pada Materi Persamaan dan Pertidaksamaan Linear Satu Variabel. Journal On Education, 01(02):309-3016.

Kumalasari, A \& Putri, R.O.P.E.(2013). Kesulitan Belajar Matematika Siswa Ditinjau dari Segi Kemampuan Koneksi Matematika. Prosiding Seminar Nasional Matematika dan Pendidikan Matematika FMIPA UNY Yogyakarta (Pp. 8-14). Yogyakarta, Indonesia : Universitas Negeri Yogyakarta.

Lerner, J.W. (2006). Learning Disabilities and Related Disorders. New York : Houghton Mifflin Company.

Mulyadi. (2010). Diagnosis Kesulitan Belajar Dan Bimbingan Terhadap Kesulitan Belajar Khusus. Yogyakarta: Nuha Litera.

NCTM. (2000). Principle and Standards for School Mathematics. Reston, VA:NCTM.

Nurrahmah. (2018). Deskripsi Kesulitan Siswa dalam Menyelesaikan Soal Matematika Materi Dimensi Tiga pada Kelas VIII. Issues in Mathematics Education, 02(2) :129-135.

Putri W, M. (2008). Analisis Kesulitan Menyelesaikan Soal Cerita Pada Pelajaran Matematika Kelas VII Semester Ganjil SMP Tri Sukses Natar Tahun Ajaran 2008/2009.(Skripsi).UNILA, Lampung.

Ruspiani. (2000). Kemampuan Siswa Dalam Melakukan Koneksi Matematika. (Tesis). Universitas Pendidikan Indonesia, Bandung.

Setiawan, A. (2009). Implementasi Model Pembelajaran Conceptual Understanding Procedures $\left(C U P_{S}\right)$ Sebagai Upaya untuk Meningkatkan Kemampuan Koneksi Matematika Siswa. (Skripsi). Universitas Pendidikan Indonesia, Bandung.

Sugiman. (2008). Koneksi Matematik dalam Pembelajaran Matematika di Sekolah Menengah Pertama. Phytagoras,04(1):56-66. 